\title{
Effect of climate change on the annual energy consumption of a single family house in British Columbia
}

\author{
Fuad Mutasim Baba* and Hua Ge \\ Concordia University, Department of Building, Civil and Environmental Engineering, Montreal, \\ Canada
}

\begin{abstract}
The Earth is already experiencing some of the effects of climate change, such as rising temperature, more frequent storms, increased precipitation, etc. This paper investigates the effect of climate change on the energy consumption of a single-family house with different energy efficiency levels, i.e. bylaw to meet current National Energy Code of Canada for Buildings (NECB), and passive house (PH) to meet the $\mathrm{PH}$ requirements under four climate zones in British Columbia, Canada. SRES A2, RCP 4.5 and RCP 8.5 emission scenarios are used to generate future climate for 2020, 2050, and 2080. The simulation results show that for both bylaw and $\mathrm{PH}$ cases, heating energy consumption will be reduced while cooling energy consumption will be increased, as a result for bylaw case, the energy consumption will be decreased for four climate zones, while for PH case, the energy consumption will be increased for zone 4 \& 5 and decreased for zone $6 \& 7$. In climate zone 5 , the building fails to meet the $\mathrm{PH}$ requirements during 2050. Therefore, buildings designed based on historical weather data will perform differently under the changing future climates, thus the efforts should be made to design buildings that are adaptable to climate change.
\end{abstract}

\section{Introduction}

Reducing greenhouse gas emissions is the key to deal with and controlling climate change. Buildings in Canada consume around 27\% of the total energy use and produce around 23\% of greenhouse gases [1]. The building industry and government have been increasing its efforts to make all new buildings to be net-zero energy ready within the next 15 years, such as the Energy Step Code in British Columbia (BC). Energy building simulation programs are used to evaluate the energy performance of buildings and confirm these buildings meet the passive house or net zero energy codes requirements. However, the Typical Meteorological Year (TMY) weather file used for simulations, represents the historical years. The NASA Global Climate Change [2] data showed that the global mean

\footnotetext{
Corresponding author: fu_baba@live.concordia.ca
} 
temperatures are rising faster with time. The hottest four years are 2016, 2017, 2015 and 2014. Also, 17 out of 18 warmest years among all 136 years recorded are since 2001. Therefore, it is important to ensure that energy designs meet the code requirements for the period of operation. Intergovernmental Panel on Climate Change (IPCC) was established to assess the scientific, technical and socio-economic information relevant for the understanding of the risk of human-induced climate change since 1988 up to now [3].

The impact of future climates on the building performance has been investigated in recent years with the majority of studies being focused on the future heating and cooling energy consumption of buildings based on third or fourth IPCC scenarios [4-6]. Most of these studies concluded that the heating demand would likely decrease over the future climates, while the cooling demand would likely increase. In USA, Shen conducted research on climate change effect on the total energy use for residential and office buildings, and found that the total energy use will be increased by up to $14 \%$ for residential buildings and reduced by up to $3 \%$ for office buildings in 2050 [7]. In UK, Jenkins et al. found that under the future climate the cooling demand of office buildings will be increased by up to $4 \%$ in 2030 [8]. However, there are limited studies on the impact of future climates on the energy performance of buildings based on the fifth IPCC report, especially for Canada. The Energy Step Code recently introduced in BC will help achieve significant reductions of energy consumption in buildings. How these energy efficient buildings optimized based on historical weather data would perform under future climatic conditions is the question this research aims to address. This paper presents the evaluation of the energy performance of a single-family house in BC built to current and future energy codes under future climatic conditions.

\section{Methodology}

The energy performance of typical residential buildings in BC are evaluated under the current and predicted future climates of 2020, 2050, and 2080 for four climatic zones, i.e. Vancouver (zone 4), Kamloops (zone 5), Prince George (zone 6), and Fort Nelson (zone 7), through simulations using DesignBuilder (EnergyPlus) [9]. Results for a typical woodframe single-family house is presented in this paper. For the energy performance assessment, the archetype construction built conforming to the current and proposed 2032 energy codes are evaluated under both current and future climatic conditions. Three emission scenarios are selected to generate future climatic conditions:

- A2 emission scenario based on fourth Intergovernmental Panel on Climate Change (IPCC) report. A2 emission scenario represents the average change of regional economic development; self-reliant countries; continuous population increase; slower and more fragmented technological changes [10]. CCWorldWeatherGen tool based on General Circulation Models HadCM3 is used to create future weather data [11]

- Cumulative distribution functions (CDF) based on Representative Concentration Pathways (RCP) 8.5 and 4.5 emission scenarios by the fifth IPCC report [12]. RCP 8.5 and RCP 4.5 scenarios represent the radiative forcing of $8.5 \mathrm{~W} / \mathrm{m} 2$ and $4.5 \mathrm{~W} / \mathrm{m} 2$ by 2100, and the equivalent $\mathrm{CO} 2$ concentrations in the year 2100 for RCP 8.5 and RCP 4.5 are $936 \mathrm{ppm}$ and $538 \mathrm{ppm}$, respectively [13]. WeatherShift [14] tool based on 14 General Circulation Models is used to create future weather data by RCP 8.5 and 4.5.

\subsection{Case study building}

The residential building sector consumes $14 \%$ of the total energy uses in Canada [1]. The latest statistics show that the average living space rose by $17 \%$ per household in 2013 compared with 1990 [1]. On the other hand, the increase in the population and the decrease 
in the number of people per family have contributed to the increase of the households' number by $40 \%$, resulting in an increase in the energy use in residential sector by $6.5 \%$ from 1990 to 2013 [1]. Therefore, single-family house is chosen as the case study for the evaluation of the effect of future climates on the energy performance. Single-family detached houses represent $53.6 \%$ of all dwelling types in Canada according to 2016 Census [15]. The selected house is a two-storey detached single-family house with a conditioned basement and ventilated attic having a roof slope of 4/12. This archetype building is similar to what was used in the guide by CanmetENERGY Natural Resources Canada [16] to represent a typical single-family house built in recent years in BC. Figure 1 shows the plans of the first and second floor. The gross floor area of the house is $178 \mathrm{~m}^{2}$ excluding the basement and the window wall ratio is $17 \%$.

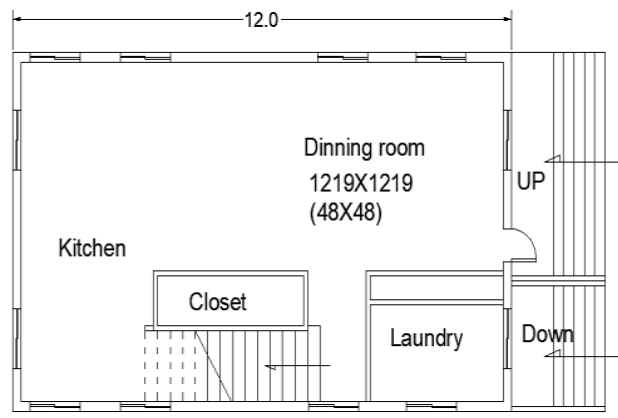

a)

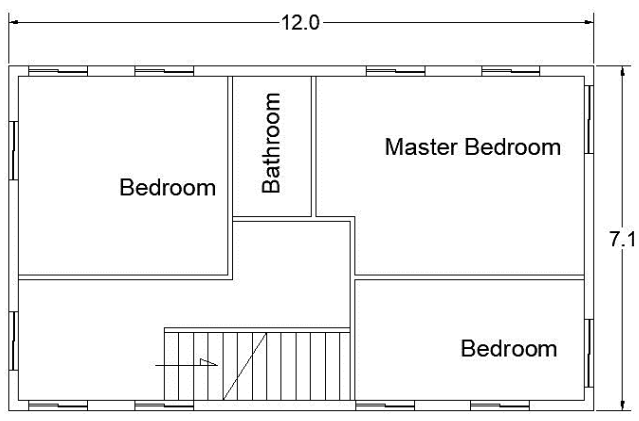

b)

Fig. 1. Floor plan of the single-family detached house: a) first floor; b) second floor. Dimension in $m$.

\subsection{Building envelope components}

The single-family detached house is a wood-frame construction. The typical building envelope components included in the single-family house are: exterior above grade wall; below-grade wall; floor; roof; and window. Two levels of building envelope designs are considered for each component, namely, bylaw and passive house (PH) designs. Bylaw design refers to building envelope assembly meets the current building code requirement for the specific climate zone, while $\mathrm{PH}$ design refers to building envelope assembly insulation levels meet the PH standard requirement. The thermal properties of component materials are listed in Table 1 for bylaw and PH case for the single-family house.

Table 1. Thermal properties of envelope components in wood frame construction for bylaw and PH case.

\begin{tabular}{l|ll|ll} 
& $\begin{array}{l}\text { Bylaw } \\
\text { Thermal transmittance } \\
\end{array}$ & $\begin{array}{l}\text { Passive house } \\
\text { Thermal transmittance } \\
\left(\mathrm{W} / \mathrm{m}^{2} . \mathrm{K}\right)\end{array}$ & & Z $)$ \\
\hline Exterior above grade wall & Zone 4 & 0.29 & Zone 4 & 0.18 \\
& Zone 5 & 0.26 & Zone 5 & 0.15 \\
& Zone 6 & 0.24 & Zone 6 & 0.10 \\
& Zone 7 & 0.21 & Zone 7 & 0.08 \\
\hline below-grade wall & Zone 4\&5 & 0.35 & Zone 6\&7 & 0.18 \\
& Zone 6\&7 & 0.27 & Zone 4\&5 & 0.15 \\
\hline roof & Zone 4 & 0.19 & Zone 6 & 0.08 \\
& Zone 5\&6 & 0.17 & Zone 7 & 0.06 \\
\hline
\end{tabular}




\begin{tabular}{|c|c|c|c|c|}
\hline floor & All zones & 0.25 & $\begin{array}{l}\text { Zone } 4 \& 5 \\
\text { Zone } 6 \& 7\end{array}$ & $\begin{array}{l}0.14 \\
0.11\end{array}$ \\
\hline window & All zones & 1.50 & $\begin{array}{l}\text { Zone } 4 \& 5 \\
\text { Zone } 6 \& 7\end{array}$ & $\begin{array}{l}0.78 \\
0.60\end{array}$ \\
\hline
\end{tabular}

\subsection{Settings in whole building energy simulations}

The settings in whole building energy simulation are provided in Table 2 for the singlefamily house.

Table 2. Whole building energy simulation settings for single-family house

\begin{tabular}{|c|c|c|c|}
\hline & UNITS & VALUE & NOTES AND REFERENCES \\
\hline Heating set point & ${ }^{\circ} \mathrm{C}$ & 21 & NBC 9.36.5.4. (5) \\
\hline Heating set back & ${ }^{\circ} \mathrm{C}$ & 18 & NEBC Table A-8.4.3.2.(1) Schedule G \\
\hline Cooling set point & ${ }^{\circ} \mathrm{C}$ & 25 & NBC 9.36.5.4. (5) \\
\hline Appliances \& plug loads & $\mathrm{W} / \mathrm{m}^{2}$ & 2.5 & NEBC Table A-8.4.3.3 (2) A. \\
\hline Lighting density & $\mathrm{W} / \mathrm{m}^{2}$ & 5 & NEBC8.4.4.6. \\
\hline Target Illuminance & Lux & 125 & NEBC Table A-8.4.3.3 (2) A. \\
\hline Bylaw infiltration rate & ACH50 & 2.5 & NBC 9.36.5.14 \\
\hline PH infiltration rate & ACH50 & 0.6 & PH requirement \\
\hline Mechanical ventilation & $\begin{array}{l}\text { L/s- } \\
\text { person }\end{array}$ & 10 & $\begin{array}{l}\text { ASHRAE } 62.2 \text { Table 6.2.2.1 } \\
\text { and NBC Table 9.32.2.3. }\end{array}$ \\
\hline $\begin{array}{l}\text { Heat Recovery } \\
\text { Mechanical ventilation }\end{array}$ & & & $\begin{array}{l}\text { Bylaw: } 60 \% \text { HRV } \\
\text { PH: } 90 \% \text { HRV efficiency for zone } 4,5 \\
\& 6 \text {, and } 93 \% \text { HRV efficiency for zone } 7\end{array}$ \\
\hline $\begin{array}{l}\text { Natural ventilation set } \\
\text { point }\end{array}$ & ${ }^{\circ} \mathrm{C}$ & 22 & $\begin{array}{l}\text { When } \mathrm{t} \text { inside }>\mathrm{t} \text { set point natural } \\
\text { ventilation will activate }\end{array}$ \\
\hline Heat pump system & \multicolumn{2}{|c|}{ Heating system } & COP depends on the climate zone \\
\hline & \multicolumn{2}{|c|}{ Cooling system } & Table 3 shows all values of COP \\
\hline
\end{tabular}

Table 3. COP of air-sourced heat pump under current and future climates

\begin{tabular}{l|llll|l} 
& WINTER & & & SUMMER \\
\hline YEARS & Vancouver & Kamloops & P. George & F. Nelson & All climate zones \\
\hline CURRENT & 2.8 & 2.2 & 1.7 & 1.5 & 3.5 \\
$\mathbf{2 0 2 0}$ & 2.8 & 2.2 & 1.7 & 1.6 & 3.5 \\
$\mathbf{2 0 5 0}$ & 2.8 & 2.5 & 2 & 1.6 & 3.5 \\
$\mathbf{2 0 8 0}$ & 3.3 & 2.7 & 2.2 & 1.8 & 3.5 \\
\hline
\end{tabular}

\section{Results and discussions}

The annual energy consumption of the single-family house under different scenarios for the four cities for bylaw case and PH case is analysed. The annual energy consumption includes electricity used for space heating, cooling, ventilation, lighting, and appliance. As shown in Fig. 2 and Table 3 for bylaw case, the annual heating and total energy consumption will be decreased over the future climates and the energy saving will be greater for the colder climate zone $6 \& 7$. The trend is similar for all four cities with some difference based on the specific climatic characteristics of the city. As shown in Table 4, under RCP 8.5 scenario the heating consumption will be decreased by $50 \%, 40 \%, 44 \%$, and $35 \%$ for Vancouver, Kamloops, Prince George, and Fort Nelson, respectively. While the cooling energy consumption is small, the increase in terms of percentage is much higher. It is $12444 \%, 281 \%, 862 \%$ and $836 \%$ for Vancouver, Kamloops, Prince George and Fort Nelson, 
respectively. The electricity consumption will be decreased by $17 \%$ for Vancouver, $16 \%$ for Kamloops, 31\% for Prince George, and 26\% for Fort Nelson, respectively. For the PH case shown in Fig. 3, the annual energy consumption will be increased for climate zone $4 \& 5$ while decreased for climate zone $6 \& 7$ and the impact of future climate on PH case is less significant than for the bylaw case, especially for colder climate zone $6 \& 7$. The trends predicted by the three scenarios are similar (Table 4 and 5).
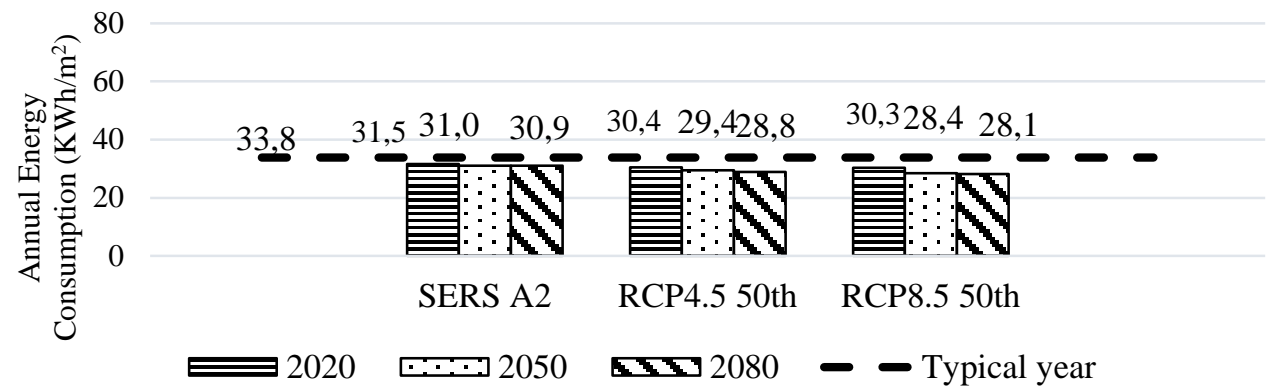

a) Vancouver

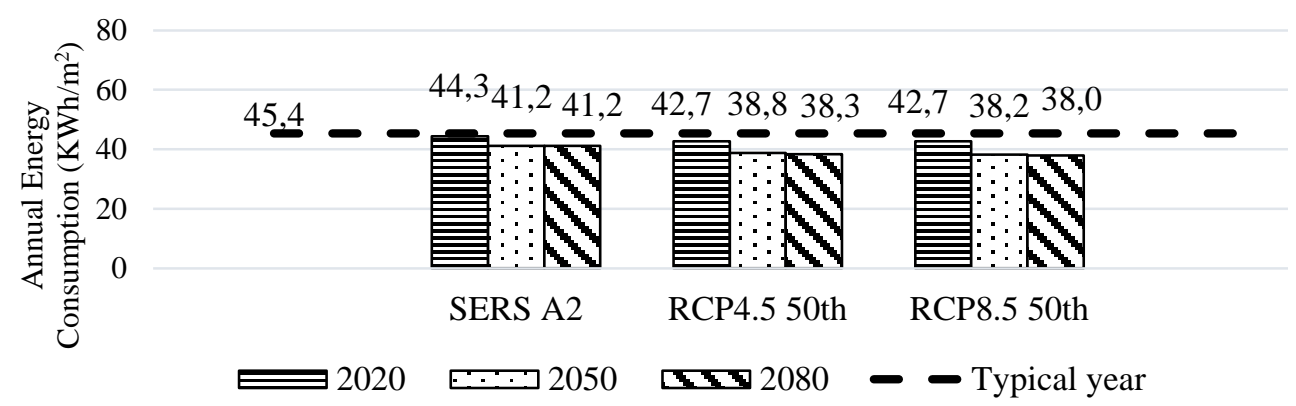

b) Kamloops

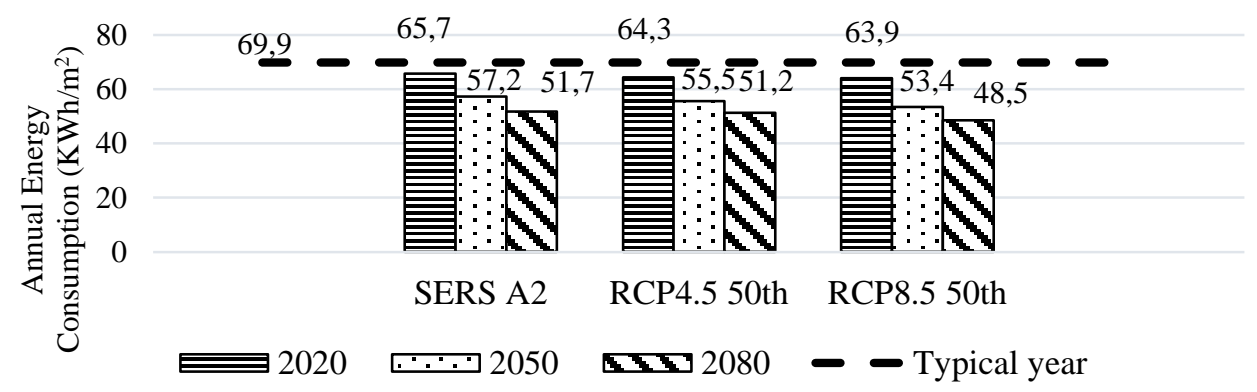

c) Prince George 

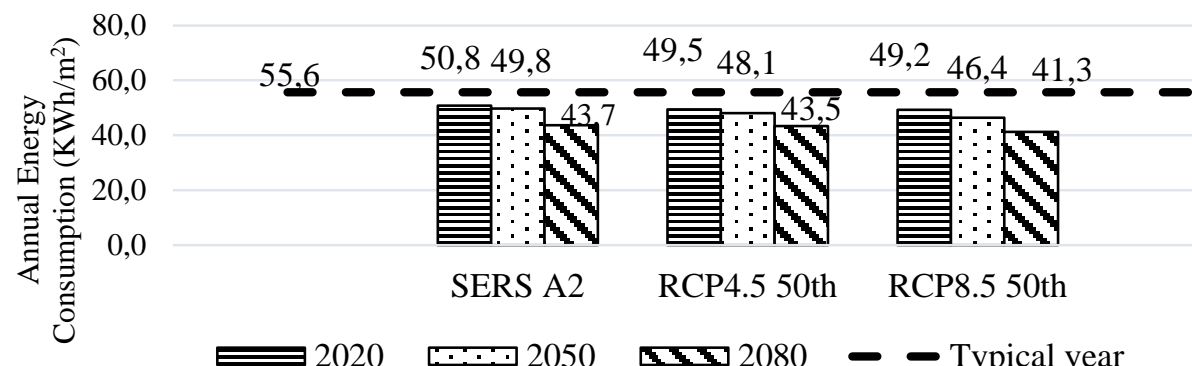

RCP8.5 50th

2020

\section{0}

$\boldsymbol{W} 2080$

- Typical year

d) Fort Nelson

Fig. 2. Annual energy consumption under different scenarios for four climate zones a) Vancouver, b) Kamloops, c) Prince George and d) Fort Nelson for bylaw case

Table 4. Change in annual heating, cooling and total energy consumption by $\%$ (from current to year 2080) for four cities under three climate change scenarios for bylaw case

\begin{tabular}{l|lll|llll|lll|lll}
\multirow{2}{*}{} & \multicolumn{3}{|c|}{ Vancouver } & \multicolumn{3}{|c|}{ Kamloops } & \multicolumn{3}{|c}{ Prince George } & \multicolumn{3}{|c}{ Fort Nelson } \\
\cline { 2 - 11 } & Heat. & Cool. & Tot. & Heat. & Cool. & Tot. & Heat & Cool. & Tot. & Heat. & Cool. & Tot. \\
\hline SERS & -40 & 13885 & -8 & -30 & 300 & -9 & -38 & 906 & -26 & -30 & 705 & -22 \\
A2 & & & & -29 & 114 & -16 & -36 & 223 & -27 & -28 & 263 & -22 \\
$\begin{array}{l}\text { RCP } \\
4.5\end{array}$ & -37 & 2137 & -15 & -29 & & & & & & & & \\
RCP & -50 & 12444 & -17 & -40 & 281 & -16 & -44 & 862 & -31 & -35 & 836 & -26 \\
8.5 & & & & & & & & &
\end{tabular}

Table 5. Change in annual heating, cooling and total energy consumption by $\% \%$ (from current to year 2080) for four cities under three climate change scenarios for PH case

\begin{tabular}{|c|c|c|c|c|c|c|c|c|c|c|c|c|}
\hline & \multicolumn{3}{|c|}{ Vancouver } & \multicolumn{3}{|c|}{ Kamloops } & \multicolumn{3}{|c|}{ Prince George } & \multicolumn{3}{|c|}{ Fort Nelson } \\
\hline & Heat. & Cool. & Tot. & Heat. & Cool. & Tot. & Heat. & Cool. & Tot. & Heat. & Cool. & Tot. \\
\hline $\begin{array}{l}\text { SERS } \\
\text { A2 }\end{array}$ & -48 & 9010 & 8 & -35 & 214 & 8 & -36 & 694 & -6 & -30 & 600 & -5 \\
\hline $\begin{array}{l}\mathrm{RCP} \\
4.5\end{array}$ & -43 & 1768 & -2 & -35 & 87 & -2 & -37 & 197 & -12 & -29 & 241 & -9 \\
\hline $\begin{array}{l}\mathrm{RCP} \\
8.5\end{array}$ & -56 & 8518 & 6 & -44 & 209 & 5 & -45 & 725 & -9 & -37 & 870 & -5 \\
\hline
\end{tabular}

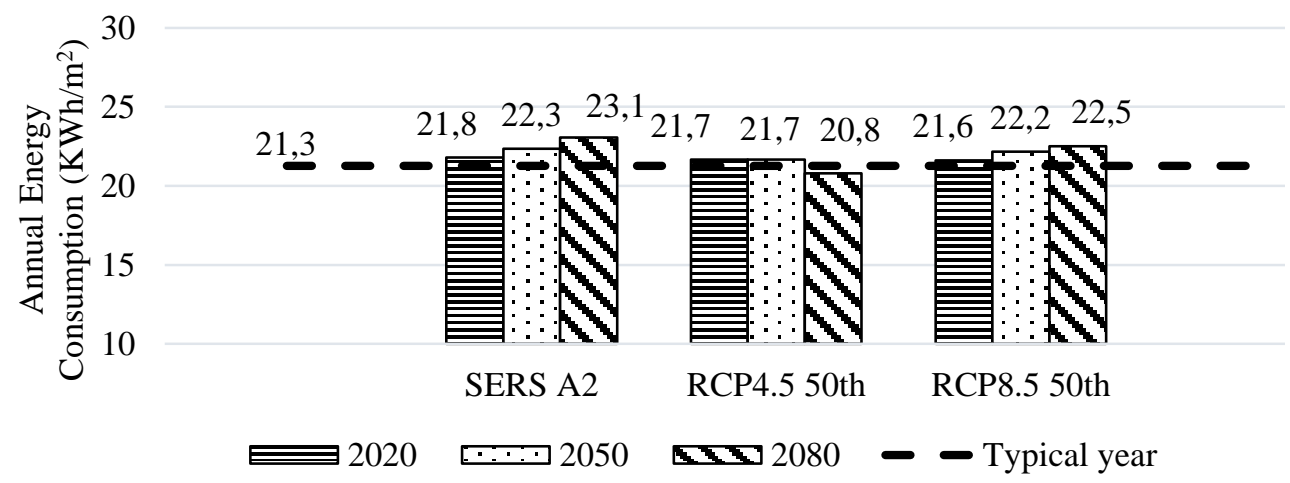

a) Vancouver 


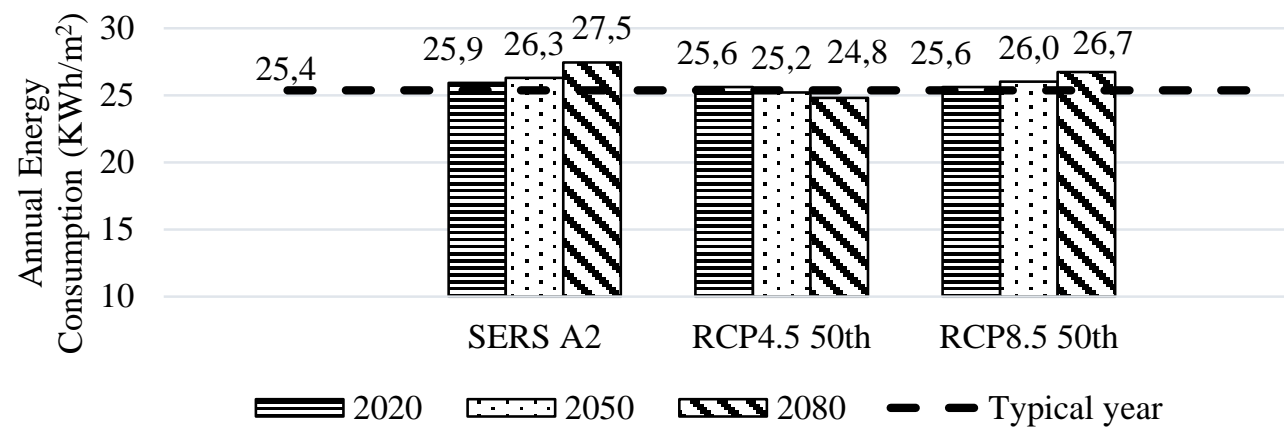

b) Kamloops

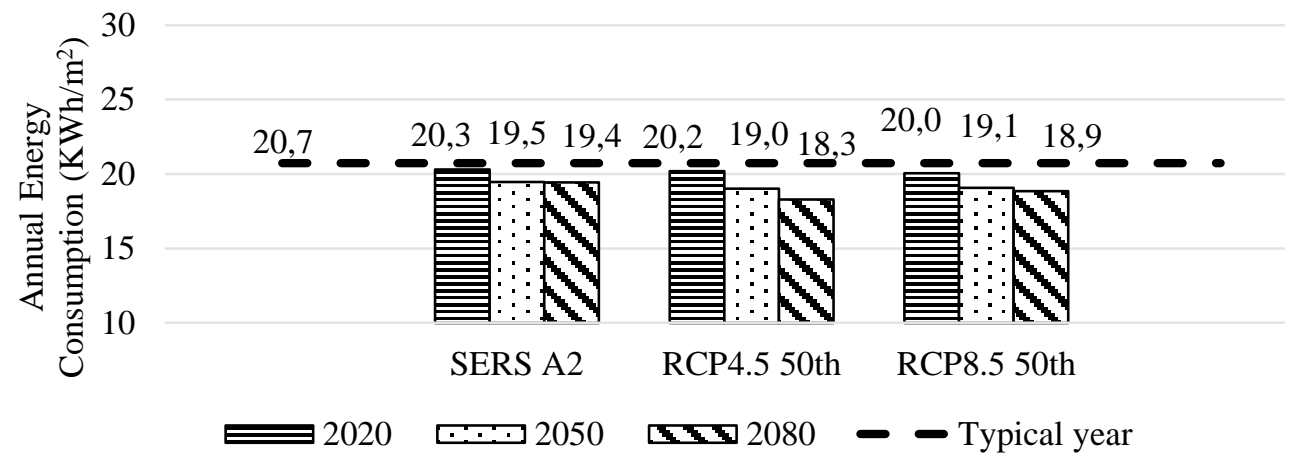

c) Prince George

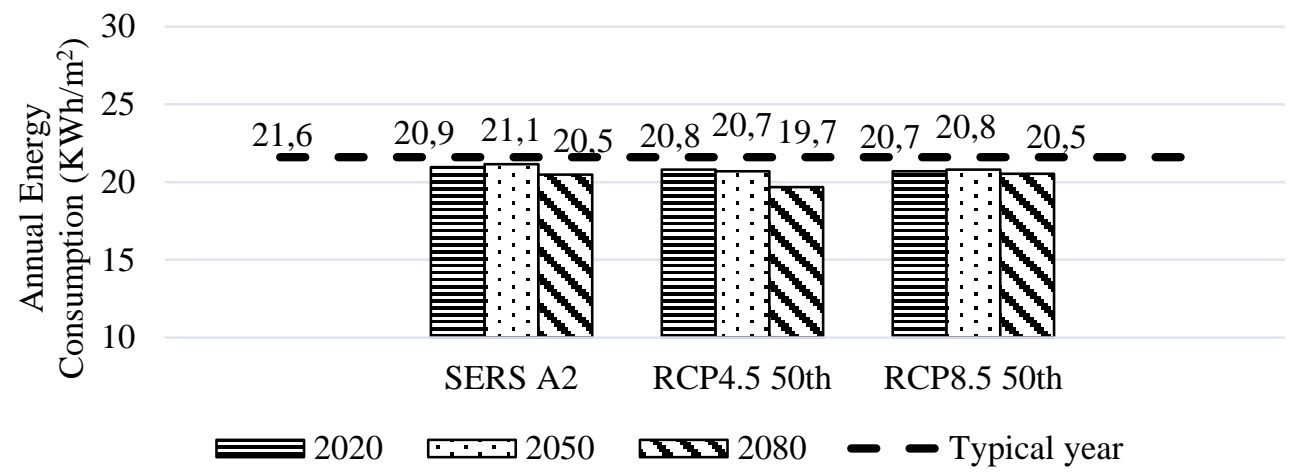

d) Fort Nelson

Fig. 3. Annual energy consumption under different scenarios for four climate zones a) Vancouver, b) Kamloops, c) Prince George and d) Fort Nelson for PH case

\subsection{Life cycle operating energy consumption}

Table 6 shows the difference in life cycle (LC) energy consumption between bylaw and PH results. Bylaw result is used as the reference. The life cycle operating energy consumption is calculated over 80 years from 2020 to 2100 . The results show that the energy saving achieved by PH house based on historical weather data will be reduced by $5-14 \%$ under a 
warming future climate depending on the climatic zones because of the significant increase in cooling energy consumption of PH house in milder climatic zone such as Vancouver.

Table 6. Difference in LC operating energy consumption between bylaw and PH case over 80 years

\begin{tabular}{l|llll} 
& Vancouver & Kamloops & Prince George & Fort Nelson \\
\hline Hist. & $37 \%$ & $44 \%$ & $70 \%$ & $61 \%$ \\
SERS A2 & $28 \%$ & $37 \%$ & $66 \%$ & $56 \%$ \\
RCP 4.5 & $27 \%$ & $36 \%$ & $66 \%$ & $56 \%$ \\
RCP 8.5 & $23 \%$ & $33 \%$ & $65 \%$ & $54 \%$
\end{tabular}

\section{Conclusions}

The effect of future climate on the building performance of a typical Canadian singlefamily house building with bylaw and Passive House standard is studied through simulations. Three weather scenarios, namely, A2 emission scenario, RCP 4.5, and RCP 8.5 , are used to generate future weather data. The evaluation is carried out for four climate zones in British Columbia. The results show that the energy consumption will be decreased over the future climates by $8-17 \%$ and the energy saving will be greater for the colder climate zones 6 \& 7 by $22-31 \%$ under bylaw codes. However, the impact of future climate on PH case is less significant than for the bylaw case. For the $\mathrm{PH}$ case, the annual energy consumption will be increased for climate zone $4 \& 5$ by $5-8 \%$ while decreased for climate zone $6 \& 7$ by $5-9 \%$. In conclusion, buildings designed based on historical weather data will perform differently under the changing future climates, thus the efforts should be placed on designing a good building to adapt to climate change.

\section{Reference}

1. Energy Efficiency Trends in Canada 1990 to 2013. 2016. Natural Resources Canada

2. NASA global climate change. https://climate.nasa.gov/vital-signs/global-temperature/

3. IPCC. Climate Change 2014: Synthesis Report. Contribution of Working Groups I, II and III to the Fifth Assessment Report of the Intergovernmental Panel on Climate Change (Core Writing Team, R.K. Pachauri and L.A. Meyer (Eds.)). Geneva, Switzerland: IPCC. (2014)

4. L. Wang, X. Liu, H. Brown. Prediction of the impacts of climate change on energy consumption for a medium-size office building with two climate models. Energy and Buildings. 157. 218-226. (2017)

5. X. Song, C. Ye. Climate Change Adaptation Pathways for Residential Buildings in Southern China. Energy Procedia. 105. 3062-3067. (2017)

6. K. Huang, R. Hwang. Future trends of residential building cooling energy and passive adaptation measures to counteract climate change: The case of Taiwan. Applied Energy. 184. 1230-1240. (2016)

7. P. Shen. Impacts of climate change on U.S. building energy use by using downscaled hourly future weather data, Energy and buildings. 134. 61-70 (2017)

8. A. Sharma, A. Saxena, M. Sethi, V. Shree, Varun. Life cycle assessment of buildings: A review. Renewable and Sustainable Energy Reviews. 15. 871-875. (2011)

9. IPCC. The Physical Science Basis-Contribution of Working Group I. to the Fourth Assessment Report of the Intergovernmental Panel on Climate Change. Cambridge University. UK. (2007)

10. H. Ge, F. Baba. Impact of Future Climates on the Energy Performance and Durability of Residential Buildings in BC. BC Housing, British Columbia, Canada. (2018) 
11. Sustainable Energy Research Group. Climate change Weather File Generator (CCWeatherGen) manual. University of Southampton. UK. (2009)

12. R. Pachauri, K. Allen, M. Barros, V. Broome, et al. Climate change 2014: synthesis report. Contribution of working groups I, II and III to the fifth assessment report of the Intergovernmental panel on climate change. IPCC. (2014).

13. M. Meinshausen, S. J. Smith, K. Calvin, J. S. Daniel, al. The RCP greenhouse gas concentrations and their extensions from 1765 to 2300. Climatic Change. (2011)

14. WeatherShift. http://www.weather-shift.com/. (retrieved 2018)

15. Census in Brief Dwellings in Canada. 2016. Statistic Canada. Retrieved from http://www12.statcan.gc.ca/ , (retrieved 2018)

16. A. Parekh. Representative Housing Thermal Archetypes for Energy Analysis Models. CanmetENERGY Ottawa. Natural Resources Canada. (2012) 